\title{
EFEKTIVITAS MODEL COOPERATIVE INTEGRATED READING AND COMPOSITION (CIRC) TERHADAP KEMAMPUAN MENGIDENTIFIKASI UNSUR-UNSUR TEKS PUISI PADA SISWA KELAS VIII SMP MUHAMMADIYAH 05 MEDAN TAHUN PELAJARAN 2018/2019
}

\author{
Sri Rahmadani ${ }^{1}$, Annisa $^{2}$, Dani Sukma Agus Setiawan ${ }^{3}$ \\ Universitas Prima Indonesia ${ }^{1}$, Universitas Prima Indonesia ${ }^{2}$, Universitas Prima Indonesia ${ }^{3}$ \\ Pos-el: sri.rahmadani96@yahoo.com ${ }^{1}$, rindi.nisa48@gmail.com ${ }^{2}$, \\ danisukmaagussetiawan@unprimdn.ac.id ${ }^{3}$
}

\begin{abstract}
ABSTRAK
Masalah dalam penelitian ini adalah kemampuan siswa mengidentifikasi unsure teks puisi masih rendah dan masih kesulitan dalam menuangkan ide dalam menulisnya. Oleh karena itu, peneliti ini bertujuan untuk medekskripsikan ada Efektivitas Model Cooperative Integrated Reading and Composition (CIRC) Terhadap Kmemapuan Mengidentifikasi Unsur Teks Puisi pada siswa kelas VIII SMP Muhammadiyah 05 Medan Tahun Pelajaran 2018/2019. Populasi penelitian ini adalah jumlah keseluruhan siswa kelas VIII SMP Muhammadiyah 05 Medan ini berjumlah 90 orang dan yang menjadi sampel pada penelitian ini sebanyak 60 orang yaitu sampel yang sudah diacak. Metode penelitian ini adalah metode eksperimen. Instrument yang digunakan adalah tes mengidentifikasi unsur teks puisi dalam bentuk essai, peneliti menugaskan siswa untuk mengidentifikasi unsur teks puisi bedasarkan tema yang sudah ditetapkan, yaitu tanpa menggunakan Model Cooperative Integrated Reading and Composition (X), Pengaruh Model Cooperative Integrated Reading and Composition (Y). Dari hasil analisis data diketahui bahwa ada perbedaan antara tanpa menggunakan Model Cooperative Integrated Reading and Composition (CIRC) dan menggunakan Model Cooperative Integrated Reading and Composition (CIRC) pada siswa kelas VIII SMP Muhammadiyah 05 Medan. Tanpa menggunakan Model Cooperative Integrated Reading and Composition (CIRC) memiliki nilai rata-rata $=60,333$ (Cukup), sedangkan dengan menggunakan Model Cooperative Integrated Reading and Composition (CIRC) memiliki nilai rata-rata $=80$ (Baik). Peningkatan kemampuan mengidentifikasi unsur teks puisi dapat terlihat, dalam proses belajar mengajar maupun melalui hasil karya menulis unsur puisi oleh masing-masing siswa. Pada hasil tes siswa yang telah di observasi peneliti menunjukkan adanya Efektivitas Model (CIRC) terhadap kemampuan menulis unsur-unsur puisi lebih efektif.
\end{abstract}

Kata Kunci: Model Cooperative Integrated Reading and Composition (CIRC), Puisi.

\begin{abstract}
The problem in this study is the ability of students to identify the elements of text poetry is still low and still have difficulty in expressing ideas in writing it. Therefore this study aims to describe the Effectiveness of Cooperative Integrated Reading and Conposition (CIRC) Models The Ability to Identify Poetry Text Elements in Grade VIII Muhammadiyah Middle School 05 Medan 2018/2019 academic year population of this study is the total number of eighth grade students of Muhammadiyah Middle School 05 Medan totaling 90 people and the sample in this study were 60 people which were samples scrambled.The method of this research is the experimental method the instrument used is a test identifying elements of poetic text in essay form researchers assign students to identify elements of poetic text based on predetermined themes namely without using the Cooperative Integrated Reading Model and Composition (X),
\end{abstract}


influence of Cooperative Integrated Reading Model Composition (Y). From the results of data analysis it is known that there is a difference between without using the Cooperative Model of Integrated Reading and Composition (CIRC) and using the Cooperative Integrated Reading and Composition Model (CIRC) in class VIII Muhammadiyah Middle School 05 Medan.Without using the Cooperative Integrated Reading and Composition Model (CIRC) has an average value $=60,333$ (enough) while using the Cooperative Integrated Reading and Composition Model $(C I R C)$ has an average value $=80$ (good). Increasing the ability to identify elements of text poetry can be seen in the teaching and learning process as well as through the work of writing elements of poetry by each student. The test results of students who have been observed in the study show that the Effectiveness of the Model (CIRC) on the ability to write poetry elements is more effective.

Keywords: Cooperative Integrated Reading and Composition Model (CIRC), Poetic.

\section{PENDAHULUAN}

Karya sastra terdiri atas tiga bentuk yaitu prosa, puisi, dan drama. Prosa adalah karya sastra yang tidak terikat dengan kaidah dan aturan tertentu, seperti novel dan cerpen. Karya sastra yang berbentuk puisi adalah karya sastra yang terikat dengan kaidah dan aturan tertentu seperti syair, pantun, gurindam, dan lain sebagainya. Sedangkan puisi adalah kemampuan menulis dengan mengungkapkan, melukiskan, dan menciptakan suatu karya sastra yang dapat dituangkan dalam perasaan, pikiran seseorang dalam merangkai kata-kata yang indah sehingga pembaca tersebut dapat merasakan sendiri dari makna kata-kata puisi tersebut.

Menurut Kosasih (2017:206) menjelaskan puisi adalah bentuk karya sastra yang menggunakan kata-kata yang indah dan karya makna, keindahan sebuah puisi disebabkan oleh diksi, majas, rima, dan irama yang terkandung dalam karya sastra itu.

Puisi memiliki unsur penunjang yaitu unsur fisik dan unsur batin. Di dalam sebuah teks puisi, unsur fisik dan unsur batinlah yang menjadi pokok pembahasan. Unsur-unsur inilah yang menyebabkan karya sastra hadir sebagai unsur-unsur yang faktual akan dijumpai jika orang membaca karya sastra ataupun melihat pembacaan puisi. Unsur fisik dan unsur batin sebuah puisi adalah unsur-unsur yang (secara langsung) turut serta membangun cerita. Unsur fisik puisi meliputi: (1) Diksi, Pengimajian, (3) Kata Konkret, (4) Majas, (5) Irama/rima, dan (6) Tata Wajah. Sedangkan unsur batin puisi meliputi: (1) Tema, (2) Perasaan, (3) Nada, (4) Amanat.

Menurut Arends (dalam Suprijono, 2013:46), "Model Pembelajaran mengacu pada pendekatan yang digunakan termasuk di dalamnya tujuan-tujuan pembelajaran, tahap-tahap dalam kegiatan pembelajaran, lingkungan pembelajaran dan pengelolaan kelas". Begitu juga dalam proses pembelajaran agar dapat berhasil, sebagai pengajar, seorang guru hendaknya mampu menciptakan suasana yang lebih menarik dan tidak membosankan yaitu dengan kemampuannya merancang teknik pengajaran yang sesuai dengan menggunakan strategi dan model yang bervariasi sehingga dapat membangkit minat, motivasi dan ketertarikan siswa dalam belajar khususnya bahasa Indonesia.

Pada kenyataannya penggunaan metode pembelajaran masih terabaikan dan model yang dibuat guru hanya menonton (Konvensional) sehingga membuat peserta didik jenuh dan bosan, peserta didik sulit menuangkan ide dan gagasan dalam pikirannya ke dalam tulisan khusus pembelajaran menulis 
teks puisi. Oleh karena itu, guru perlu menentukan bagaimana model pembelajaran agar dapat memotivasi dan menarik peserta dididk untuk membaca. Dari penjelasan tersebut, satu di antaranya upaya yang mungkin dilakukan guru dalam meningkatkan kemampuan peserta didik dalam membaca khususnya membaca teks puisi adalah dengan menggunakan model pembelajaran CIRC.

Menurut Istarani (2017:112), "Model CIRC adalah pembelajaran sisa yang ditempatkan dalam tim belajar beranggotakan 4-5 orang yang merupakan campuran menurut tingkat prestasi, jenis kelamin, dan suku, guru menyajikan pelajaran kemudian siswa bekerja dalam tim mereka memastikan bahwa seluruh anggota tim telah menguasai pelajaran tersebut".

Dalam penelitian ini dibahas mengenai mengidentifikasi unsur-unsur teks puisi sesuai dengan kompetensi dasar pada mata pelajaran bahasa Indonesia di SMP yakni peserta didik dapat mengidentifikasi unsur-unsur teks puisi yang dibaca. Kemampuan untuk mengidentifikasi unsur teks puisi memang bukanlah mudah bagi peserta didik di bangku SMP. Dari hasil wawancara penulis terhadap guru pengajar, diketahui bahwa dalam proses pembelajaran bahasa dalam proses pembelajaran bahasa Indonesia khususnya untuk materi mengidentifikasi unsur-unsur teks puisi pada siswa kelas VIII SMP Muhammadiyah 05 Medan. Diketahui bahwa hanya sebagian siswa yang mendapat nilai tuntas dan selebihnya masih banyak siswa yang mendapat nilai KKM yang sudah ditentukan sekolah yaitu 70 , sementara hasil pemerolehan nilai peserta didik dalam mengidentifikasi unsur teks puisi sekitar $60 \%$ siswa masih memperoleh nilai dibawah KKM dengan memperoleh nilai kisaran 40 sampai 60.

Rendahnya kemampuan peserta didik untuk mengidentifikasi unsur teks puisi di kelas VIII-B SMP Muhammadiyah 05 pada umumnya adalah: (1) karena guru tersebut ketika mengajar hanya menggunakan metode konvensional yaitu ceramah sehingga siswa kesulitan dalam mennentukan unsur-unsur teks puisi tersebut, (2) pada pelaksanaan pembelajaran mengidentifikasi unsur-unsur teks puisi yang dilakukan guru belum melibatkan siswa untuk berpikir kritis karena siswa hanya ditugaskan menjawab soal sesuai buku pelajaran, (3) kegiatan guru dalam proses pembelajaran dengan penggunaan metode belum tepat dalam mengidentifikasi unsur puisi, (4) media yang digunakan kurang bervariasi dan berkisar pada buku teks pelajaran bahasa Indonesia kelas VIII, (5) metode yang digunakan guru seperti metode penugasan dan ceramah kurang merangsang peserta didik untuk aktif dalam belajar.

Sehubungan dengan masalah yang dihadapi siswa tersebut, penulis akan mencoba menerapkan model CIRC untuk meningkatkan kemampuan peserta didik dalam menentukan unsur teks puisi tersebut. Model CIRC merupakan model pembelajaran khusus mata pelajaran bahasa dalam rangka membaca dan menemukan ide pokok, pikiran, atau tema sebuah wacana. Untuk melaksanakan model CIRC ini supaya dapat berjalan dengan baik, diperlukan komponen-komponen yang menunjang diantaranya tersebut adalah sebagai berikut: (1) tim diperlukan pembentukkan kelompok kecil beranggota 4-5 orang, (2) pengelompokkan tersebut haruslah didasarkan pada kemampuan yang dimiliki para siswa, (3) kreativitas upayakan tenaga pendidik mampu merangsang kreativitas yang dimiliki para siswanya, (4) belajar kelompok tersebut terdapat kelompok yang membutuhkan tenaga pendidiknya, (5) selanjutnya memberikan penghargaan 
kepada kelompok belajar yang memiliki hasil kerja kelompok yang baik.

Berdasarkan hal tersebut, maka penulis melakukan penelitian dengan judul penelitian "Efektivitas Model Cooperative Integrated Reading dan Composition (CIRC) Terhadap Kemampuan Mengidentifikasi Unsur Teks Puisi Pada Siswa Kelas VIII SMP Muhammadiyah 48 Medan”.

\section{METODE PENELITIAN}

Arikunto (2010:50) menyatakan bahwa "Metode Penelitian adalah strategi umum yang dianut dalam pengumpulan dan analisis data yang diperlukan guna menjawab persoalan yang dihadapi.

Adapun metode yang digunakan dalam penelitian ini adalah metode kuantitatif. Karena data penelitian ini berupa analisis statistik yang menggunakan angka-angka. Metode ini digunakan karena peneliti ingin mengetahui "Efektivitas Model Cooperative Integrated and Composition (CIRC) terhadap Kemampuan Mengidentifikasi Unsur-Unsur Teks Puisi pada siswa kelas VIII SMP Muhammadiyah 48 Medan Tahun Pelajaran 2018-2019".

Penelitian ini Telah dilaksanakan di Sekolah Menengah Pertama (SMP) Muhammadiyah 05 yang beralamat Jalan Bromo Gang Aman, Kec. Tegal Sari Mandala III, Kab. Medan Denai. Adapun alasan penulis memilih SMP ini akan dijelaskan dengan singkat dibawah ini:
a. Jumlah siswa di SMP
Muhammadiyah 05 memadai untuk dijadikan sampel penelitian.

b. Di SMP tersebut berdasarkan pengetahuan penulis belum pernah dilakukan penelitian yang serupa dengan masalah penelitian yang sama.

\section{A. Teknik Analisa Data}

1) mencari nilai rata-rata (mean) dengan rumus:

$$
\begin{aligned}
& M_{X_{1}}=\frac{\sum f X}{N} \\
& M_{X_{1}}=\text { Nilai } \\
& \text { variabel } \mathrm{X}_{1} \\
& \sum f X_{1}=\text { Jumlah } \text { rata-rata } \\
& \text { frekuensi dengan skor (nilai) } \\
& \text { variabel } \mathrm{X}_{1} \\
& \mathrm{~N} \quad=\text { Banyaknya subjek }
\end{aligned}
$$$$
\text { yang diteliti }
$$

2) mencari standar deviasi dengan rumus:

$$
S D_{X_{1}}=\sqrt{\frac{\sum f x^{2}}{N_{1}}}
$$

$S D_{X_{1}}=$ Deviasi standard dari sampel yang diteliti

$\sum f x^{2}=$ Jumlah perkalian frekuensi dengan skor (nilai) yang dikuadratkan

$N_{1} \quad=$ Banyaknya subjek yang diteliti

3) mencari standar error dengan rumus:

$$
\begin{aligned}
& S E_{M X 1}=\frac{S D_{X 1}}{\sqrt{N-1}} \\
& S E_{M X_{1}}=\text { Besarnya kesalahan } \\
& \text { mean sampel } X_{1} \\
& S D_{X_{1}}=\text { Deviasi standard dari } \\
& \text { sampel yang diteliti } \\
& \mathrm{N} \quad=\text { Banyaknya subjek yang } \\
& \text { diteliti } \\
& 1 \quad \text { Bilangan konstan } \\
M_{x_{2}}= & \frac{\sum f X_{2}}{N} \\
& M x_{2}=\text { Nilai rata-rata variabel } \mathrm{X} \\
2 \quad & \sum f X_{2}=\text { Jumlah perkalian }
\end{aligned}
$$

frekuensi dengan skor (nilai) variabel $\mathrm{N}=$ Banyaknya subjek yang diteliti

2) mencari standar deviasi dengan rumus:

$$
S D_{x_{2}}=\sqrt{\frac{\sum f X_{2}{ }^{2}}{N_{1}}}
$$




$$
\begin{aligned}
& S D_{x 2}=\text { Deviasi standard dari } \\
& \text { sampel yang diteliti } \\
& \sum f X_{2}{ }^{2}=\text { Jumlah perkalian } \\
& \text { frekuensi dengan skor } \\
& \text { (nilai) yang } \\
& \text { dikuadratkan } \\
& N_{1}=\text { Banyaknya subjek yang }
\end{aligned}
$$

4. Uji Persyaratan Analisis Data

a. Uji normalitas

Untuk pengujian hipotesis nol tersebut, kita tempuh prosedur sebagai berikut:

a) pengamatan dijadikan bilangan baku $z_{1}, z_{2}, \ldots . z_{n}$ dengan menggunakan rumus $z_{i}=\frac{x_{i}-\bar{x}}{s}(\bar{x}$ dan $\mathrm{s}$ masing-masing merupakan ratarata dan simpangan baku sampel),

b) untuk tiap bilangan baku ini menggunakan daftar distribusi normal baku kemudian dihitung $\mathrm{F}\left(z_{i}\right)=\mathrm{P}\left(z \leq z_{i}\right)$

c) selanjutnya dihitung proposi $z_{1}, z_{2}, \ldots . z_{n}$ yang lebih kecil atau sama dengan $z_{i}$ jika proporsi ini dinyatakan oleh $\mathrm{S}\left(z_{i}\right)$, maka

$$
\begin{aligned}
& \mathrm{S}\left(z_{i}\right)= \\
& \frac{\text { banyaknya } z_{1}, z_{2}, \ldots z_{n} \quad \text { yang } \leq z_{i}}{n}
\end{aligned}
$$

d) hitung selisih $\mathrm{F}\left(z_{i}\right)-\mathrm{S}\left(z_{i}\right)$ kemudian tentukan harga mutlaknya, dan

e) ambil harga yang paling besar di antara harga-harga mutlak selisih tersebut (Lo).

b. Uji homogenitas

Uji homogenitas bertujuan untuk mengetahui apakah data mempunyai varian yang sama (homogen) atau tidak. Rumus yang digunakan adalah :

$$
\mathrm{F}=\frac{S_{1}^{2}}{S_{2}^{2}}
$$

Keterangan :

$\mathrm{S}_{1}{ }^{2}=$ Varian dari kelompok lebih besar

$\mathrm{S}_{2}{ }^{2}=$ Varian dari kelompok lebih kecil

Kriteria pengujian :

Jika $\mathrm{F}$ hitung $<\mathrm{F}$ tabel maka kedua sampel mempunyai varian yang sama.

Jika F hitung > F tabel maka kedua sampel tidak mempunyai varian yang sama.

6. Uji hipotesis

Uji hipotesis penelitian dilakukan dengan menggunakan uji " $\mathrm{t}$ " (Sudijono, 2005: 282-285) dengan rumus sebagai berikut:

$$
t_{0}=\frac{M_{1}-M_{2}}{S E_{M 1-M 2}}
$$

Keterangan:

$$
\begin{array}{ll}
\mathrm{t}_{0} & =\mathrm{t} \text { observasi } \\
\mathrm{M}_{1} & =\text { Mean hasil post-test } \\
\mathrm{M}_{2} & =\text { Mean hasil pre-test }
\end{array}
$$

$\mathrm{SE}_{\mathrm{M} 1-\mathrm{M} 2}=$ Standar error perbedaan kedua kelompok

Di mana $S E_{M}=\frac{S D}{\sqrt{N-1}}$

$$
S E_{M I-M 2}=\sqrt{S E_{M 1}+S E_{M 2}}
$$

Dengan demikian jika $t_{0}>t_{t}$ maka $\mathrm{H}_{0}$ ditolak dan $\mathrm{Ha}$ diterimapada taraf nyata $\alpha=0.05$ dan dikonsultasikan dengan tabel "t.

\section{HASIL DAN PEMBAHASAN Hasil Penelitian}

Penelitian ini merupakan penelitian yang melibatkan dua kelas yang diberi perlakuan yang berbeda yaitu kelas eksperimen dan kelas kontrol. Masing-masing siswa terdiri dari 30 siswa, satu kelas sebagai kelas eksperimen dan kelas yang lainnya sebagai kelas kontrol. Selama penelitian 
dilakukan semua sampel mengikuti seluruh kegiatan penelitian. Penelitian ini menggunakan metode eksperimentwo group post-test design only. Penelitian ini terdiri dua variabel yaitu variabel kemampuan mengidentifikasi unsurunsur teks puisi dengan modelCooperative Integrated Reading and Composition (CIRC) $\left(\mathrm{X}_{1}\right)$ disebut kelas eksperimen dan variabel kemampuan mengidentifikasi unsurunsur teks puisimenggunakan model ceramah $\left(\mathrm{X}_{2}\right)$ disebut kelas kontrol.

\section{Pembahasan}

Berdasarkan kriteria pengujian yaitu menerima sampel berasal dari populasi berdistribusi normal jika diperoleh $L_{\text {hitung }}<\mathrm{L}_{\text {tabel }}$ dan menolak kriteria pengujian jika syarat tidak dipenuhi. Dari tabel tersebuthasilposttest kelas kontrol diperoleh $\mathrm{L}_{\text {hitung }}<\mathrm{L}_{\text {tabelyakni }} \quad 0,1587<\quad 0,1617$ danhasilpost-test kelas eksperimen diperoleh $\mathrm{L}_{\text {hitung }}<\mathrm{L}_{\text {tabel }}$ yakni $0,1333<$ 0,1617 . Dengan demikian kedua data menerima kriteria pengujian bahwa sampel berasal dari populasi berdistribusi normal.

\section{Uji Homogenitas Data}

\begin{tabular}{|c|c|c|c|c|c|}
\hline N & Data & Varians & $\mathrm{F}_{\text {hitung }}$ & $\mathrm{F}_{\text {tabel }}$ & $\begin{array}{c}\text { Kesimpula } \\
\mathrm{n}\end{array}$ \\
\hline 1 & Post-test & & & & \\
& Kontrol & 108,50 & & & \\
& & 6 & 1,49 & 1,85 & Homogen \\
\hline 2 & Post-test & & & 8 & \\
& Eksperime & 72,414 & & & \\
& $\mathrm{n}$ & & & & \\
\hline
\end{tabular}

Berdasarkan tabel tersebut data post-test kontrol diperoleh varians = 108,506 dan post-test eksperimen diperoleh varians 72,414 . Oleh karena itu, kedua sampel diperoleh pengujian $\mathrm{F}_{\text {hitung }}<\mathrm{F}_{\text {tabel }}$ yakni1,498 $<1,858$ maka hal ini membuktikan bahwa sampel dari populasi yang homogen.

\section{Uji Hipotesis}

Berdasarkan perhitungan yang telah dilakukan. Maka dapat diketahui bahwa thitung >ttabel yakni $4,131>2,002$. Dengan demikian, hipotesis nihil (Ho) ditolak dan hipotesis alternatif (Ha) diterima. Berdasarkan data tersebut, maka dapat disimpulkan bahwa Model Cooperative Itegrated Reading and Composition (CIRC). Memiliki pengaruh terhadap kemampuan mengidentifikasi unsur-unsur teks puisi pada siswa kelas VIII SMP Muhammadiyah 05 Medan Tahun Pelajaran 2018/2019.

\section{SIMPULAN}

Berdasarkan hasil penelitian yang dipaparkan pada bab sebelumnya dapat disimpulkan bahwa kemampuan siswa dalam mengidentifikasi unsur-unsur teks puisi di kelas kontrol dengan menggunakan model ceramah diperoleh mean (rata-rata) 60,333 termasuk dalam Kategori Cukup (C). Maka dapat diketahui bahwa kemampuan mengidentifikasi unsur-unsur teks puisi pada siswa kategori sangat baik sebanyak 0 siswa atau 0\%, kategori baik sebanyak 9 siswa atau 30\%, kategori cukup sebanyak 13 siswa atau 43\%, kategori kurang sebanyak 7 siswa atau $23 \%$, dan kategori sangat kurang 1 siswa atau 3\%. Identifikasi hasil Post-Test tersebut dalam kategori cukup.

Kemampuan mengidentifikasi unsur-unsur teks puisi dengan menggunakan model Cooperative Integrated Reading and Composition (CIRC) diperoleh mean (rata-rata) 80 termasuk dalam kategori B (Baik). Maka dapat diketahui bahwa kemampuan mengidentifikasi unsur-unsur teks puisi siswa termasuk kategori sangat baik sebanyak 11 siswa atau 37\%, kategori baik sebanyak 17 siswa atau 57\%, kategori cukup sebanyak 2 siswa atau 
$7 \%$, kategori kurang sebanyak 0 siswa atau $0 \%$, dan kategori sangat kurang sebanyak 0 siswa atau $0 \%$.

Maka dapat diketahui bahwa thitung >ttabel yakni 4,131> 2,002. Dengan demikian, bila thitung lebih besar dari ttabelberarti $\mathrm{Ha}$ diterima. Sehingga dapat disimpulkan bahwa model Cooperative Integrated Reading and Composition (CIRC) memiliki pengaruh terhadap kemampuan mengidentifikasi unsur-unsur teks puisi siswa kelas VIII SMPMuhammadiyah 48 Medan tahun pelajaran 2018/2019.

\section{DAFTAR PUSTAKA}

Agus Suprijono. 2013. Cooperative Learning Teori dan Aplikasi PAIKEM. Yogyakarta: Pustaka Pelajar.

Arikunto, S.2007. Dasar-Dasar Evaluasi Pendidikan. Jakarta: Rineka Cipta.

Arikunto, S. 2010. Prosedur Penelitian Suatu Pendekatan Praktik. Jakarta: RinekaCipta.

Fristi. (2012). Pengaruh Model Pembelajaran CIRC Terhadap Kemampuan Menentukan Fakta dan Opini Pada Tajuk Rencana Harian Kompas Oleh Siswa XI SMA Islam Terpadu Al-Ulum Tahun Pembelajaran 2012/2013”. [Online].

Hardi Kurniawan. (2011). Pengaruh Model Pembelajaran Kooperatif Tipe CIRC Terhadap Kemampuan Membaca Kritis Teks Eksplanasi Siswa Kelas VII MTs N 13 Jakarta Selatan Tahun Pelajaran 2016/2017'. [Online].

Istarani. 2017. 58 Model Pembelajaran Inovatif. Jakarta: Perpustakaan Nasional

Imas Kurniasih dan Berlin Sani 2016. Ragam Pengembangan Model Pembelajaran. Jakarta: Kata Pena.

Kosasih. 2017. Ketatabahasaan dan Kesusasteraan. Bandung: Yrama
Widya.

Nurhadi. 2016. Tujuan Mengidentifikasi. Jakarta: Bumi Aksara.

Nurhasanah. 2015. Pengaruh Model Pembelajaran SAVI Terhadap Kemampuan Menulis Naskah Drama Siswa Kelas XI SMA Swasta Yapim Biru-biru Tahun Pelajaran 2018/2019”. Skripsi FKIP UNPRI Medan: tidak diterbitkan.

Poerwadarminto W.J.S. 1976. Kamus Besar Bahasa Indonesia. PN Balai Pustaka: Jakarta.

Rokhmansyah, Alfian. 2014. Studi dan Pengkajian Sastra. Yogyakarta: Graha Ilmu.

Rusman. 2015. Model-model Pembelajaran. Jakarta: PT. Rajsa Grafindo Pustaka

Samroh (2012). "Efektivitas Penggunaan Teknik Cooperative Integrated Reading and Composition (CIRC) Terhadap Peningkatan Hasil Belajar Membaca cerpen Siswa Kelas VII SMP Swasta Budi Agung Medan Marelan Tahun Pembelajaran 2009/2011". [Online].

Slavin, Robert E. 2005. Cooperative Learning: Theory, Research and Pratice. London: Allymand Bacon.

Shoimin, A. 2016.Model Pembelajaran Inovatif dan Kurikulum 2013. Yogyakarta: Ar-ruz Media.

Sudjana. 2016. Metode Statistika. Bandung: Trasito.

Sugiyono. 2017. Metode Penelitian Kuantitatif dan Kualitatif dan $R \& D$. Bandung: Alfabeta.

Umry Hadi Shafwan dan Winarti. 2011. Sastra Mandiri (telaah Puisi. Medan: Format Publishing.

Waluyo, Herman J. 2005. Apresiasi Puisi. Jakarta: Gramedia Pustaka Utama. 